\title{
Culture Teaching in Moroccan EFL Secondary Schools
}

\author{
Mohamad Akharraz \\ University of Ibn Zohr \\ moahamad.akharraz@edu.uiz.ac.ma
}

Dr. Youssef Tamer

University of Ibn Zohr

y.tamer@uiz.ac.ma

DOI: http://doi.org/ 10.36892/ijlls.v3i2.579

\begin{tabular}{|c|c|}
\hline $\begin{array}{l}\text { Received: } \\
\text { 01/05/2021 }\end{array}$ & $\begin{array}{l}\text { Abstract } \\
\text { To empower Moroccan students to join the rapidly growing globalized world, }\end{array}$ \\
\hline $\begin{array}{l}\text { Accepted: } \\
\text { 08/06/2021 }\end{array}$ & $\begin{array}{l}\text { the Ministry of education, through multiple official documents, incessantly } \\
\text { calls for culture incorporation in the teaching of foreign languages. While the } \\
\text { existing research studies on culture in the Moroccan EFL context have } \\
\text { considerably revolved around textbook analysis, no study known to the }\end{array}$ \\
\hline $\begin{array}{l}\text { Keywords: culture } \\
\text { teaching, cultural } \\
\text { perspectives, EFL } \\
\text { teaching, cultural } \\
\text { practices, cultural } \\
\text { products. }\end{array}$ & $\begin{array}{l}\text { researcher, has explored the real classroom practices of culture teaching in } \\
\text { Moroccan secondary schools. Hence, this study explores how culture is being } \\
\text { treated by the teaching practitioners at Moroccan secondary EFL classrooms } \\
\text { - second-year Baccalaureate level. The thematic analysis of the data collected } \\
\text { from } 76 \text { EFL instructors at Souss Massa Academy, through online } \\
\text { questionnaires and interviews, has shown that the research participants } \\
\text { demonstrated a good understanding of the culture teaching. However, the } \\
\text { findings exhibited that plenty of challenges have made the linguistic } \\
\text { components continue to pre-empt the significant portion of time in the } \\
\text { classroom teaching. Based on the reported hurdles, a set of recommendations } \\
\text { for the EFL teachers, ELT supervisors, textbook and curriculum designers, } \\
\text { and further research were highlighted. }\end{array}$ \\
\hline
\end{tabular}

\section{INTRODUCTION}

Prompted by the belief that enhancing students' awareness of their own and other cultures serves as a basis for developing intercultural competence, the Ministry of education in Morocco, through various official documents, recommends incorporating cultures in foreign language instruction. English Language Guidelines for Secondary Schools (2007), a significant reference source to all the parties concerned with the EFL teaching in Morocco, explicitly states that culture is one of the five areas that should be addressed by English teaching in level four. By learning the English language, learners understand their culture(s) and other cultures regarding their perspectives, practices, and products (the 3Ps). However, while the syllabus (Guidelines) is explicit about the primary goals for teaching cultures and the types of cultures to stress (the 3Ps), it does not clearly show to the teaching practitioners how to incorporate culture in the classroom practices in the same way they should teach vocabulary and grammar. For example, what target culture to stress, what approaches to use, what culture content to highlight, and how culture should be assessed. In light of this ambiguity in culture teaching, we know little about how culture is being treated in EFL teaching. This study aims at exploring the classroom practices of culture teaching at the second-year Baccalaureate level. It will touch upon (1) teachers'perceptions of incorporating cultures in EFL teaching, (2) the practices teachers use to facilitate the incorporation of culture in their classrooms, (3) teachers' perceptions of the textbook in use as a source of 
culture teaching, and (4) the challenges encountered while teaching cultures. Therefore, the central research questions addressed in this exploratory study are the following:

1. What are the EFL teachers' perceptions regarding the incorporation of cultures in EFL teaching to second-year Baccalaureate students?

2. What practices do teachers use to facilitate the incorporation of cultures in their classrooms?

3. What are the teachers' perceptions of the textbook as a source of cultural teaching and learning?

4. What are the significant challenges encountered by the EFL teachers in the teaching of culture?

\section{LITERATURE REVIEW}

\subsection{Terminology}

Multiple answers to what culture is have generated a large number of definitions to the concept in question to the extent that some of them are "contradictory, inconsistent, and ultimately, confusing" (Moran, 2001, p. 23). Because it is an "enigma" (Ting-Toomey, 1999, p. 9) and a broad concept (Aleksandrowska, 2015; Lafayette, 1978; Moran, 2001; Peterson, 2004; Schulz, 2007; Seelye, 1993), culture is not uniformly defined by various academic scholars. Kroeber and Kluckhohn (1954) scrutinized 300 definitions to isolate the common denominator and concluded that a precise common denominator was not found (as cited in Seelye, 1993, p.15). Culture is defined as "a way of life" (Brown, 2007, p. 188). Brooks (1968) divided culture into a formal culture and deep culture. Culture is also classified depending on the importance of themes. For example, grand themes are categorized under "Culture" with capital C, whereas minor themes are categorized under culture with lowercase c (Peterson, 2004, p. 24). Bennett et al. (1998) referred to Culture with capital C and culture with lowercase c as objective and subjective. Objective culture is defined as "cultural creations including institutions (...) and artifacts of formal culture". Subjective culture is referred to as "psychological features that define a group of people - their everyday thinking and behaviors - rather than to the institutions they have created" (p. 3).

\subsection{Lanaguage and Culture}

A considerable body of research on teaching culture has revealed that both language and culture are inextricably related. That is, language cannot be divorced from culture and the other way around (e.g., Brown, 2000; Damen, 1987; Fantini, 1997; Kramsch, 1998; Liddicoat, 2001; Mahmoud, 2015; Pesola, 1997; Robinson-Stuart \& Nocon, 1996; Schulz, 2007; Spinelli \& Siskin, 1992; Valdes, 1990). Brown (2007), for example, pointed that "the language is a part of culture, and a culture is a part of a language; the two are intricately interwoven so that one cannot separate the two without losing the significance of either language or culture" (p. 189). Metaphorically echoed by Jiang (2000), "language is flesh, and culture is blood. Without culture, language would be dead; without language, culture would have no shape" (p.328). Moran (2001) described language as a window to the culture (p. 35). This close relationship has led to the birth of new words; Kramsch (1989) coined the word linguaculture, whereas Agar (1994) coined linguaculture (as cited in Moran, 2001, p. 35).

To fully reveal the relationship between language and culture, one has to examine the nature of language. Kramsch (1998) identified three ways in which language and culture are interwoven. First, language expresses cultural reality. In other terms, words are the window for the stock of knowledge members of a community share. Second, language embodies cultural reality in that the appropriate selection of language, through all its verbal and nonverbal aspects, generates meanings that the discourse community members understand. Third, language symbolizes cultural reality in that language, as a set of signs, stands for a cultural value for its speakers and makes them different from the outsiders. The language they use 
reflects their culture and an inseparable part of their own culture. "The prohibition of its use is often perceived by its speakers as a rejection of their social group and their culture" (p. 3).

\subsection{The Role of Culture in Langauge Learning}

Traditionally, culture treatment in foreign language classrooms did not receive much attention as the focus was on the linguistic components of the language. Wintergerst and McVeigh (2011) pointed out "up through the 1970s and beyond, many foreign language courses had the primary goal of helping students become sufficiently fluent to read literature in the target language" (p. 121). Similarly, Grittner (1990) stated that the culture in the various Grammar and Translation Method courses revolved around literature. Although the textbooks included some cultural elements (e.g., pictures of famous people, churches, and castles), these items had little or nothing to do with the ongoing business of learning (p. 19). Similarly, the Direct Method lessons incorporated the history of the people who speak the target language and the geography of the country or countries where the language is spoken (Larsen-Freeman, 2000, p. 29). Likewise, the Audio-lingual Method has viewed culture as inseparable from the teaching of language in the sense that textbooks included notes in English to make students familiar with similarities and differences between American culture and the target culture (Grittner, 1990).

Recently, multiple factors have dragged culture from the margin to the center of the language course content. First, the growing number of immigrants crossing borders for different reasons necessarily entails a degree of familiarity with the people's culture in those communities. Therefore, it is the schools' job to inform them about the new country'straditions and culture through curricula, syllabi, and textbooks. Liddicoat (2001) pointed out that cultural knowledge has become more important for foreign language teaching throughout the world. Thus, it has been rapidly incorporated into the curriculum documents, syllabuses, and textbooks (p. 47). This growing awareness among educationalists as to the centrality of culture in language proficiency attainment stemmed essentially from the inextricable relation between culture and language (Brown, 2000; Damen, 1987; Fantini, 1997; Liddicoat, 2001; Pesola, 1997; Robert-Stuart \&Nocon, 1996; Schulz, 2007; Spinelli \& Siskin, 1992; Valdes, 1990). What does this close relationship between language and culture tell us about language teaching/learning? To answer this question, one has to identify the primary goal of language education. Undoubtedly, developing communication ability in another language is one of the fundamental push factors that drive people to enroll in a language course.

Nevertheless, is the knowledge of grammar alone sufficient for these language learners to successfully achieve mutual understanding while communicating with people whose language they are learning? Kramsch, Cain, and Murphy-Lejeune (1996) pointed out that knowledge of a person's language is no guarantee of mutual understanding if one does not, at the same time, gain an understanding of that person's culture (p. 99). In other words, learners of another language, irrespective of their capability to speak that language fluently, cannot effectively and appropriately communicate unless they understand the social and philosophical content of that language, or else they run the risk of becoming fluent fool (Bennett, 1993, p. 16). These students are more likely to culturally misbehave when invited into a different social context where speakers have different language-culture backgrounds and are more likely to develop negative attitudes towards native speakers.

In a similar vein, Hall (1959) stated that "culture is communication" (p. 119) and "communication is culture" (Fantini, 1997, p. 5). Assuming culture as fabrics of meanings that we attributed to the world around us, language is a tool that exteriorizes those perceptions of the world. As such, speakers of a language seldom find it hard to understand one another simply as they share the perceptions of reality embodied in the lexicon and the structure of the language they use. Mutual understanding among members of this community is taken for granted thanks to shared frames of cultural reference. Therefore, communication 
is more manageable and effortless. However, when two different interlocutors from different cultural backgrounds meet, mutual understanding is not always easy to achieve. Steele (1989) pointed out that speakers of a different language have different perceptions of reality; no two languages show a one-to-one correspondence between vocabulary items and grammatical structures. Eventually, for language teachers to help their learners better understand the speakers whose language they are learning, cultural representations should be stressed.

By teaching another language, teachers implicitly and explicitly offer students the possibility to transcend their singular worldview (Fantini, 1997). One way to facilitate this transcendence is to help students understand the cultural meanings encoded in the linguistic signs used by native speakers of the target language. Here lies the role of the teachers. Before showing how understanding happens, it is relevant to state the assumption that "no two languages are ever sufficiently similar to be considered as representing the same social reality (Sapir, 1949, pp. 68-69, as cited in Kramsch, 2014, p. 32). Dahl (2016) addressed three aspects of learning a new language, which language teachers should know before anything else. The three aspects are understanding, misunderstanding, and lack of understanding. Firstly, understanding is achieved when students connect the unknown to what is known. To simplify this connection, students should compare the lexicon and structures with those used in the target language. If students' frames of cultural reference comprise the meaning being communicated, not necessarily the linguistic items (symbols) attributed to that meaning, understanding is achievable through comparison. Lack of understanding arises when students have no terms to connect the new word. Misunderstanding occurs when one of the interlocutors makes a connection but to the wrong reference. Therefore, it is the teacher's role to ensure that the connection is correct to avoid misunderstanding and lack of understanding. Finally, broad access to cyberspace, mass media, and social media have exposed their users to other cultures from various uncontrolled websites, channels, and social networks. This daily exposure to other cultures through uncontrolled sources is more likely to affect the users' identity and attitudes to the extent that they might develop stereotypes about other cultures. Therefore, it is the job of schools in general and foreign language education, in particular, to stop that from happening by assisting learners to localize themselves in "the third place" (Kramsch, 1993). The boundary that "grows in the interstices between the cultures the learners grew up with and the new cultures he or she is being introduced to" (Kramsch, 1993, p. 236).

Language is a means of communication and, in the meantime, a carrier of culture (Kramsch, 1998). The culture a language carries is the reality of people who speak it. Kramsch (1998) further explains that "language expresses cultural reality," and Kramsch added that when language is used in the context of communication, it is always a carrier of culture. As such, culture is no longer an optional skill or an appetizer that adds interest to a language (Yang \& Chen, 2016, p. 1130), and it is not an "expendable fifth skill" (Kramsch, 1993, p.1). Any language treatment in isolation from its cultural content disregards the nature of language (Byram, 1989). Another reason why culture has been deemed inevitable in the foreign language classroom is to develop tolerance and empathy with others (Quist, 2000, p. 4).

The emergence of foreign language learning standards in the $21^{\text {st }}$ century (National Standards in Foreign language Education Project, 1999) has brought culture to the forefront in learning foreign languages (Dema \& Moeller, 2012; Lange, 2003; Phillips, 2003). The standards-based approach defines culture based on three interconnected dimensions; the three poles of equilateral triangles are products, practices, and perspectives (Moran, 2001). Simply put, products mean artifacts; practices mean actions; perspectives mean meanings (unspoken rules). Example of products can be tangible (e.g., buildings and clothing) and intangible (e.g., written and spoken language, and music); examples of practices include greetings, weddings, and ways of celebrating); examples of perspectives are the role of individualism, and religious beliefs. 
It is worth mentioning that the labels (3Ps) appear to be compatible with many contemporary theories and models. For example, Fantini and Fantini (1997) used "artifacts (things people make), socio-facts (how people come together and for what purpose), and mentifacts (what people think or believe) (p. 57). Moran (2001) cited other educators and scholars who defined culture, language, and communication using a similar triangle. For example, products, behaviors, ideas (Nemetez-Robinson, 1988; Tomalin \& Stempleski, 1993); artifacts, behaviors, knowledge (Spradley, 1980); form, distribution, meaning (Lado, 1986); form, distribution, meaning (Larsen-freeman, 1987) (p. 24).

\subsection{Goals for Culture Teaching}

Scholars agree that culture is the core of language learning/acquisition irrespective of the challenges and the predominance of grammar in teaching foreign languages (Benattabou, 2020). Among the fundamental goals for including culture in the teaching of foreign languages are (1) to avoid cultural misunderstandings in the globalized world, (2) to promote respect, sensitivity, and empathy, (3) to learn about the differences and similarities between cultures, and finally (4) to concretize the role of education and the nation-state.

Unlike the past, the globalization of world economies, along with the growth of international telecommunications and the easy access to cyberspace, has incredibly increased the likelihood of people interacting with others from different cultures (Byram, 2008; Dahl, 2016; Risager, 2007; Robinson-Stuart \& Nocon, 1996). When these human encounters occur, either face to face or virtually, some degree of interaction is inescapable. Because they come from different areas and backgrounds, their communication is shaped by their cultural definitions, worldviews, and traits. These traits may appear strange and shocking to those in contact. For the outsiders to interact with the insiders in the new settings and transmit their intended messages, they should have adequate information, understanding, and sensitivity to their culture (insiders' cultures). For example, they should keep in mind that "many speech events, including in-service encounters, phone interactions, and classroom interactions have their culture-specific structures and routines and that many speech acts use culture-specific variations (Schulz, 2007, p. 9). In every speech community, members share common frames of cultural reference to which they unconsciously resort to when interpreting behaviors. When speakers of a language move to another speech community, understanding is not taken for granted. For both insiders and outsiders to understand and be understood, they have to have some degree of awareness of one another culture (Benattabou, 2020). Put differently, "individuals cannot use the same norms of behavior outside their culture, expecting they would function the same" (Reid, 2014, p 28).

As stated earlier, people communicate not only through spoken and written languages but also through non-verbal communication (Benattabou, 2020). Dahl (2016) defined nonverbal communication as communication without words, in contrast to verbal communication, which is oral communication through words (p. 182). This sort of communication encompasses facial expressions and sounds that are not words, such as intonation patterns. It additionally includes proxemics, kinesics, and haptics (Wintergerst \& McVeigh, 2011, p. 54). Why is having some degree of awareness of non-verbal communication so crucial? What does this learning tell us about intercultural understanding? Ting-Toomey (1999) pointed out that if language is the key to the core of a culture, non-verbal communication is the heart of each culture. Non-verbal communication is pervasive throughout a culture (p. 120). More than this, some scientists contend that 50 to 80 percent of the information transmitted during communication is conveyed using non-verbal signs and signals (Dahl, 2016, p. 181). This significant amount of communication through non-verbal communication is widely acknowledged; for example, the anthropologist Ray Birdwhistell (1974) found that more than 65 percent of a conversation is communicated through non-verbal cues (as cited in Wintergerst \& McVeigh, 2011, p. 55). Non-verbal communication varies from one culture to another as each speech community interprets its gestures and body language differently. 
Therefore, understanding non-verbal communication in form and function is of paramount importance when communicating across cultures (Benattabou, 2020). Other examples of non-verbal communication forms are gestures, eye contact, the smile, the face, posture, and pointing.

Similarly, teaching another culture provides learners with opportunities to go beyond the limitations of their worldview and helps foster their understanding of their own culture, be it local or national, which may eventually lead them to strengthen their own identity. By learning another culture, learners can develop their awareness of their own culture with its positives and negatives through comparing and contrasting. A memorable quote among interculturalists states that "if you want to know about water, do not ask a goldfish." That is, those who never experienced another culture nor labored to communicate through a second language are often unaware of the milieu in which they have always existed (Fantini, 1997, p. 13). Therefore, for students to appreciate their own culture and glorify their own identity, they should be exposed to other cultures either through face-to-face or through print and audio-visual materials. However, this learning process should be done cautiously; it should highlight both similarities and differences. Stressing similarities and ignoring the differences can generate tensions between the home and the target cultures. According to Standards for Foreign Language Learning for the $21^{\text {st }}$ Century (2006), teachers are recommended to present similarities first. Prioritizing similarities tends to set up "a favorable mindset toward speakers of the other language" (p.49). "It is essential, however, that cultural differences not be swept under the pedagogical rug. It is the differences in world view and the behavior patterns based on those differing assumptions and values that give rise to misunderstanding and conflict" (p. 49). Likewise, Cook (1972) argued that similarities between two languages are quickly learned in teaching language skills, whereas the differences or points of contrast are more challenging to master. As a result, we tend to spend much time on them. The same can be applied to culture teaching: students effortlessly accept customs, social organizations, and values similar to theirs. Teachers should spend more time on the differences because they may lead students to react negatively to speakers of other languages (p. 98).

In addition to communication purposes and language and culture relation, teaching culture has been deemed necessary if we look at the significant education purposes. Byram (2008) pointed out that there are three primary purposes for education: to socialize young people to the nation state-society, develop human capital, and create equality of opportunity (pp. 23-24). These three primary purposes of education are so important to those who teach foreign languages. If their teaching is confined to inculcating the grammatical system of the target language and the skills of using that knowledge of grammar to bridge the information gap, the three purposes mentioned above have little if any value.

\section{METHOD}

This research study adopted an exploratory sequential design to interpret and explain the data collected from the research participants. "An explanatory sequential mixed methods design consists of first collecting quantitative data and then collecting qualitative data to help explain or elaborate on the quantitative results" (Creswell, 2012, p. 542). The researcher in this study collected quantitative data using questionnaires to have a comprehensive picture of culture teaching practices in Moroccan EFL classrooms at secondary schools. In order to refine and explain the general picture, the researcher employed a qualitative data-gathering tool embodied in the interviews.

\subsection{Participants and Settings}

The target population in this case study was the secondary school EFL teachers at Souss Massa Academy in Morocco. The participants in this study were 76 teachers teaching English as a foreign language at Moroccan public schools. More specifically, teachers who 
have never taught second-year Baccalaureate-level were excluded from the study. The tables below display their gender, age category, and years of experience distribution:

Table 1

The Number of the Respondents in Gender and Percentage

\begin{tabular}{lcc}
\hline Gender & Number of respondents & Percentage \\
\hline Male & $\mathbf{6 7}$ & $\mathbf{8 8 \%}$ \\
\hline Female & $\mathbf{9}$ & $\mathbf{1 2 \%}$ \\
\hline
\end{tabular}

Table 2

Qualification of the Respondents

\begin{tabular}{lccc}
\hline Qualification & BA holders & MA holders & Ph.D. holders \\
\hline The number of respondents & $\mathbf{4 6}$ & $\mathbf{3 0}$ & $\mathbf{2}$ \\
\hline percentage & $\mathbf{6 0 . 5} \%$ & $\mathbf{3 9 . 5 \%}$ & $\mathbf{2 . 6 \%}$ \\
\hline
\end{tabular}

Table 3

Years of Experience of the Respondents

\begin{tabular}{lccccc}
\hline Years of experience & Less than 1 & $1-5$ & $6-10$ & $11-15$ & More than 16 \\
\hline $\begin{array}{l}\text { The number of } \\
\text { respondents }\end{array}$ & 1 & 23 & 19 & 9 & 24 \\
\hline Percentage & $1.3 \%$ & $30.3 \%$ & $25 \%$ & $11.8 \%$ & $31.6 \%$ \\
\hline
\end{tabular}

\subsection{Instrumentations}

As stated earlier, the researcher used two instruments to gather data from the participants.

\subsubsection{Questionnaires}

The primary purpose for using questionnaires in this study was to gather data about (1) teachers' goals for the teaching of EFL, (2) their classroom practices of culture teaching, (3) their perceptions of the mandated textbook as a source for language and culture teaching, (4) the main challenges encountered while incorporating cultures, and (5) their recommendations to improve culture teaching in the Moroccan EFL context. The questionnaire involved four clusters with an opening statement illustrating the primary purpose of the study and promising confidentiality to all the participants. To attain variety, the researcher purposefully included open-ended questions, multiple-choice questions, and closed questions. However, the predominance of multiple-choice questions was meant to maximize the response rate and help the respondents complete the questionnaires quickly. In so doing, the researcher would exert some control over the answers given. Nevertheless, all the multiple-choice questions were followed by "other" so that the respondents can add other answers which are not mentioned in the pre-defined responses.

To ensure that the questionnaire was reliable and valid, the researcher provided clear instructions. Also, the items were structured to make sure that the content was relevant to the purpose of the study. Because it is easier to overlook mistakes and ambiguities in question layout and construction while designing a questionnaire, the researcher piloted the instrument with some colleagues. They were asked to answer the questionnaires and provide feedback on any ambiguous questions that can be restated or formulated.

\subsubsection{Interviews}

As formerly stated, the key reason behind using the interviews was to gather more data from the respondents who wanted to provide more information that could not otherwise be elicited using the questionnaires. Therefore, the interview questions were based on those from the questionnaires. Like the questionnaires, the interview draft comprised five clusters: (1) teachers' goals for the teaching of EFL, (2) teachers' classroom practices of culture teaching, (3) teachers' perceptions of the textbook as a mandatory source for language and 
culture teaching, (4) the main challenges faced by the EFL teachers while integrating cultures, and (5) teachers' recommendations to improve culture teaching in the Moroccan EFL context. To ensure that the interview was valid and reliable, the researcher asked some colleagues to proofread it.

\subsection{Procedure}

As soon as the questionnaires were devised and validated, the researcher administered them online, using Google Docs. The participants'Facebook accounts and their email addresses were used to disseminate the link to the questionnaire. Although the link was widely dispatched to a large number of high school teachers at Souss Massa Academy, only 76 teachers completed the questionnaires. Concerning the interview data, the researcher opted for the purposive sampling approach. A few accessible teachers who are locally thought to be more experienced were kindly asked to sit for the interviews. Some of them were contacted through emails, while others were met face to face. The purposive sample of 20 EFL teachers was chosen for the interviews based on experience, reputation, and interest. Twelve of the interviewees have been teaching EFL for about 14 years. Others have been teaching EFL for more than six years. Additionally, this chosen sample is well-known for its high level of commitment and hard work. This would increase the reliability and validity of the information elicited from them.

\subsection{Data analysis}

A big part of the data collected from the questionnaires was analyzed statistically based on the participants' answers. Pie and bar charts were used to present the numerical data, followed by the researcher's description and interpretation. During the analysis, the data from the interviews were analyzed thematically and employed to crosscheck and elaborate on those elicited via questionnaires.

\section{FINDINGS}

\section{Cluster 1. Teachers'Goals for the Teaching of EFL}

Figure 1. Teachers' Goals for Teaching EFL.

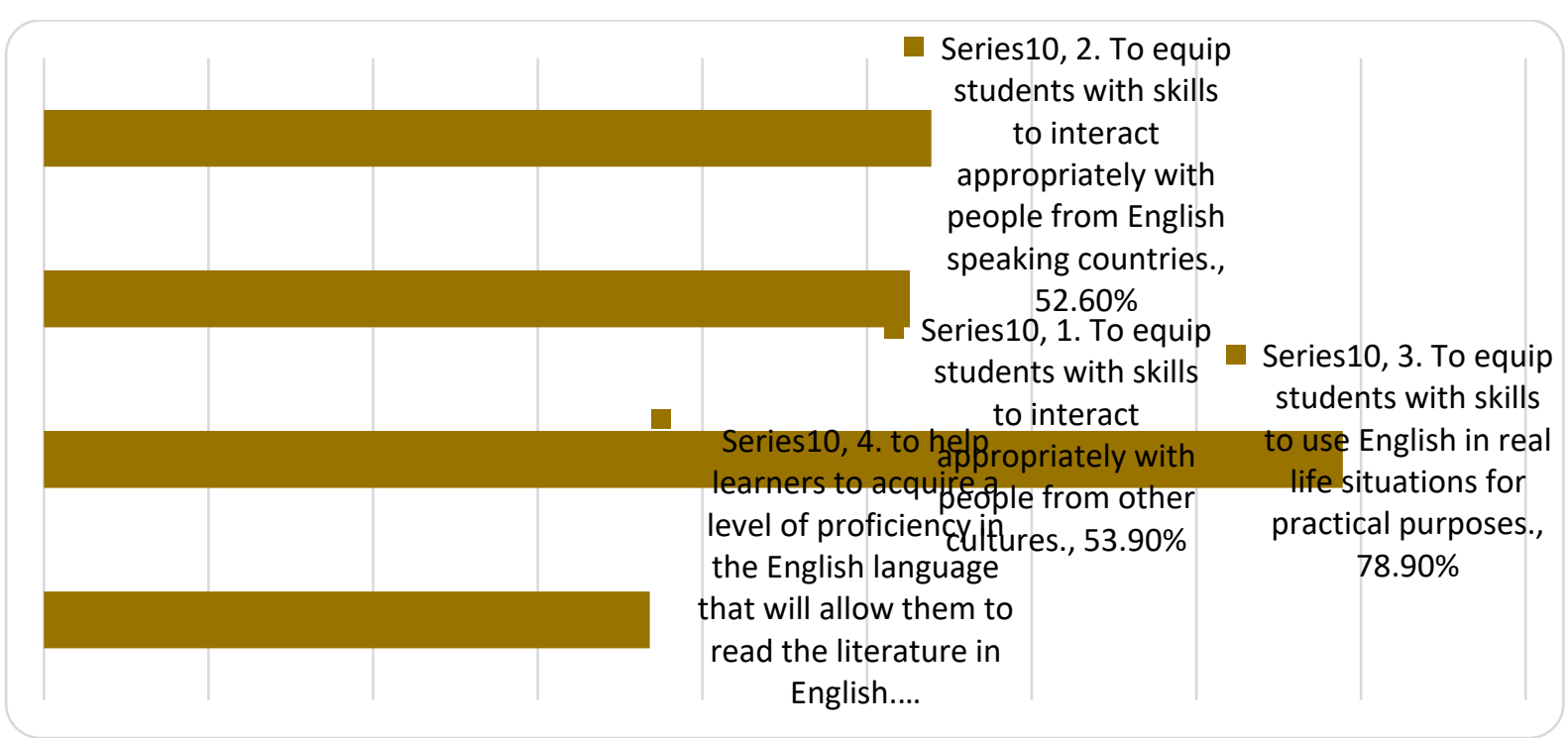

Figure 1 shows that a large number of participants teach English to equip students with skills to use in real-life situations for practical purposes. However, developing students' proficiency levels to read literature in English was not the center of attention for the research 
participants. In the same vein, 40 research participants teach English to equip their learners with skills to interact appropriately with people from English-speaking countries.

\section{Cluster 2. Teachers'Beliefs of Culture in the Teaching of EFL}

1. How would you define culture and intercultural competence in the context of foreign language education?

To identify how the participants conceptualize culture and intercultural competence in the context of foreign language education, they were asked to provide their definitions of the two concepts. A content analysis of the given definitions exhibited that every teacher conceptualized culture and intercultural competence differently. However, there were a lot of recurrent words in teachers'definitions. For example, they referred to culture as life, culture as daily practices, and culture as customs and traditions; cultural competence is the ability to use language appropriately. Also, most definitions equated culture with communication. Teachers also referred to the language as a carrier of culture, and therefore, students should develop an awareness of their own and others' cultures.

Figure 2. Teachers' Beliefs of theEFL Teaching Objectives

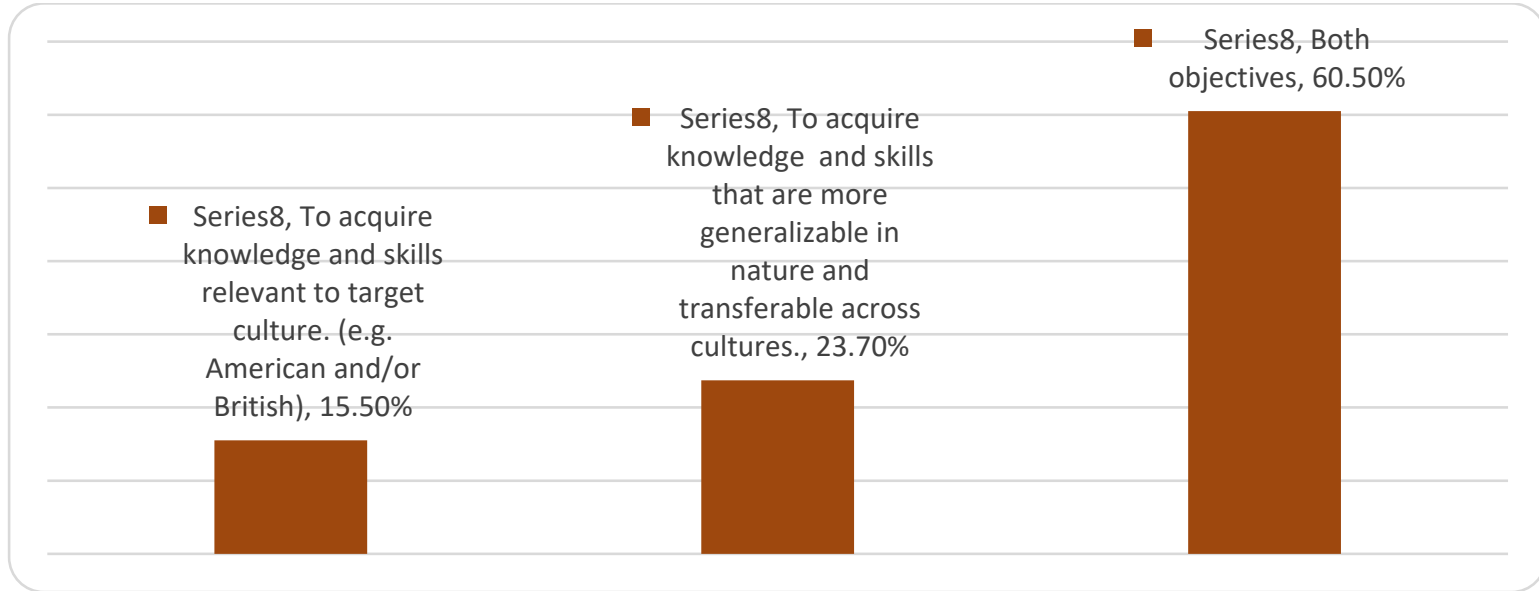

Figure 2 demonstrates that almost $70 \%$ of the participants believe that both objectives should be at the heart of EFL learning. That is, teachers should help their learners acquire knowledge and skills relevant to target cultures whose language students are learning, and acquire knowledge and skills that are more transferable across cultures. However, $24 \%$ think that culture teaching should be restricted to the target culture whose language students are learning, whereas $23.70 \%$ think it should involve international cultures. Data from the interviews revealed that while the respondents agreed that students should be aware of the native speakers' target cultures, they firmly believed that they should develop familiarity with other cultures. Among the arguments highlighted during the interviews were: (1) the teaching of cultures should promote cross-cultural dialogue, (2) enhancing students' life-long culture learning skills, (3) English has become an international language and no longer exclusive to any specific culture, (4) culture teaching should help learners avoid culture shocks, negative stereotypes, and communication breakdowns in unpredictable situations, and (5) culture teaching/learning should also boost learners' self-confidence, foster understanding, and promote pride in learners' identity.

\section{Cluster 3. The Classroom Practices of Culture Teaching}

Figure 3. Teachers' Incorporation of Cultures in the Second-Year Baccalaureate Classes 


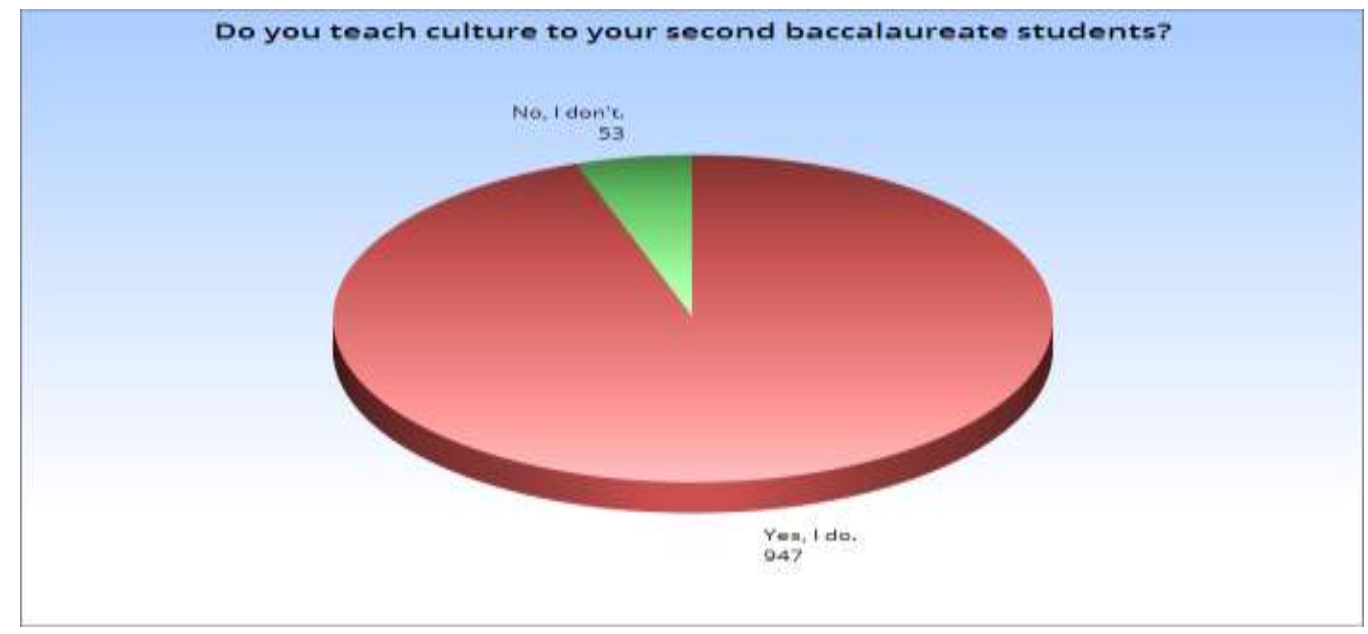

The respondents were asked if they teach culture to second-year Baccalaureate students or not. Figure 3 exhibits that $94,7 \%$ of the participants teach culture in their teaching of EFL, whereas $5.3 \%$ do not. To elicit more data, the researcher asked the participants to state their reasons for excluding culture in the language classroom. Those who drop culture argued that: (1) culture is rarely incorporated in the second-year Baccalaureate syllabus, (2) students can learn culture from other sources like the Internet, (3) the mandated textbooks relegate culture to the end of the units, meaning that teachers may cover it if they wish, and (4) culture is not tested, and therefore no need to teach it.

Table 4

Culture Teaching Activities

\section{Statements}

(1) Discussion of similarities and differences in table manners, appropriate behaviors for wedding ceremonies, greetings, interviewing, etc., in Morocco and other countries.

(2) Types of food, musical instruments, systems of education, etc., in Morocco and other countries.

(3) Discussion of the significance of education, sports, humor, etc., in Morocco and other countries.

(4) How people order meals, address one another, etc., in Morocco and other countries.

(5) Discussion of perceptions and attitudes towards women, youth, independence, etc., in Morocco and other countries.

(6) Names of singers, athletes, politicians, and their achievements in Morocco and other countries. always sometimes rarely never
51

20

38

18

42

$10 \quad 3$

$6 \quad 1$

2

1

6

$18 \quad 11$

The inclusion of this item was to elicit the extent to which the research participants develop students' knowledge of cultural products, cultural practices, and cultural perspectives. According to the data displayed in Table 4, activities (Items 1,2,4, and 6) are sometimes included by the teachers. However, activities (Items 3 and 5) are rarely used. The frequency use of activities implies that the respondents favored the activities that address 
products (Item 2 and 6) and practices (Items 1 and 4). In contrast, those addressing cultural perspectives failed to grab teachers' attention. Substantial data from the interviews further explained teachers' tendency towards cultural products and practices more than perspectives. Most teachers argued that delving into the underlying significance of products and practices requires time and a high level of language proficiency on the part of the learners. Also, the currently-used textbooks seldom refer to values, attitudes, and perceptions governing both practices and products.

\section{Cluster 4. Teachers'Opinions of the Currently-used Textbooks as a Source of Culture Teaching and Learning.}

Figure 4. Teachers' Beliefs of the Place of InterculturalCompetencein the Textbooks

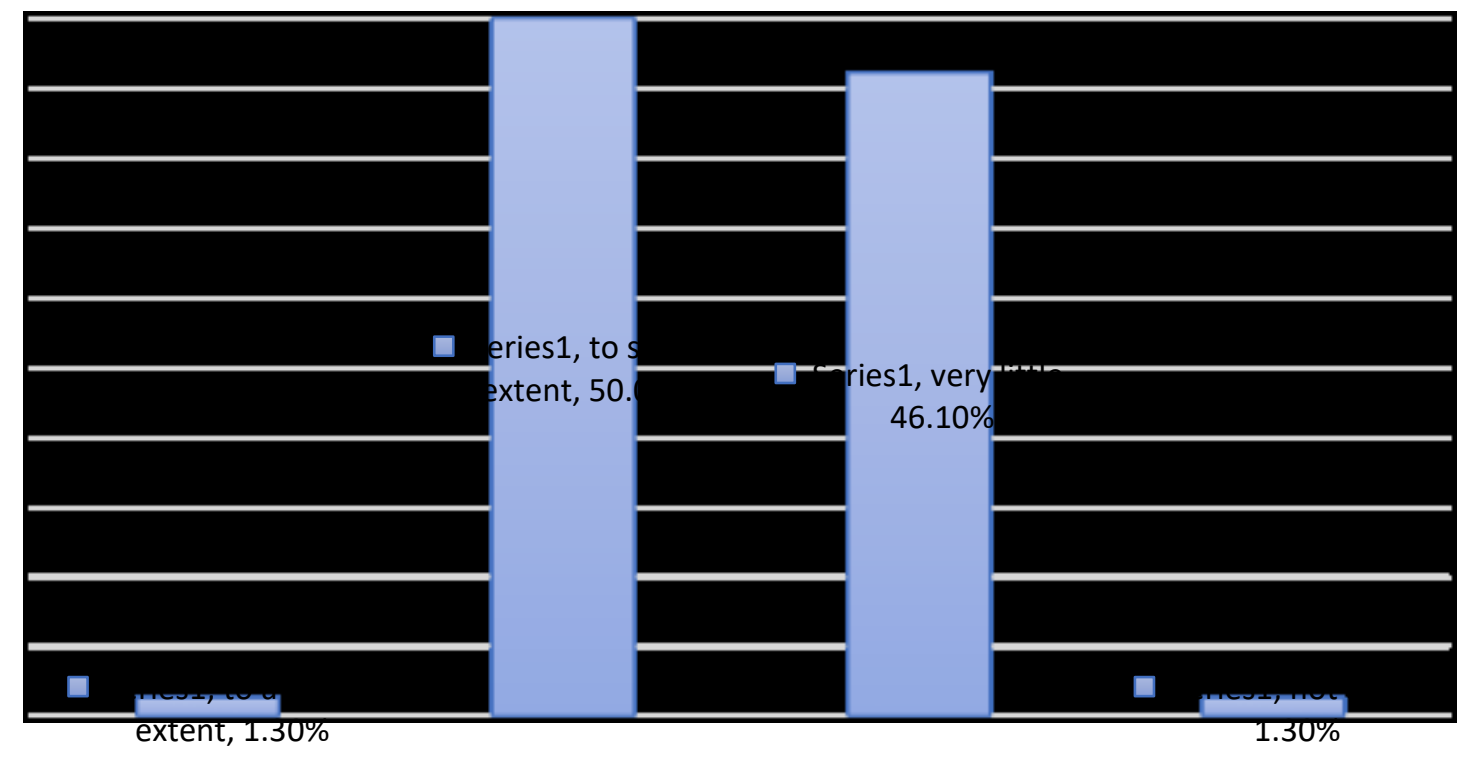

The participants were asked if the currently-used textbooks offer opportunities for their learners to develop their intercultural competence. According to Figure 4,50\% of the participants believed that the textbooks in use provide, to some extent, language learners with opportunities to boost their intercultural competence. However, $46 \%$ of the participants thought that these opportunities are minimal. Interview-based data further exhibited that most of the participants were critical of the currently-used textbooks with respect to cultural content. It was reported that the cultural content is limited.

Figure 5. Sources of CultureTeaching Material 


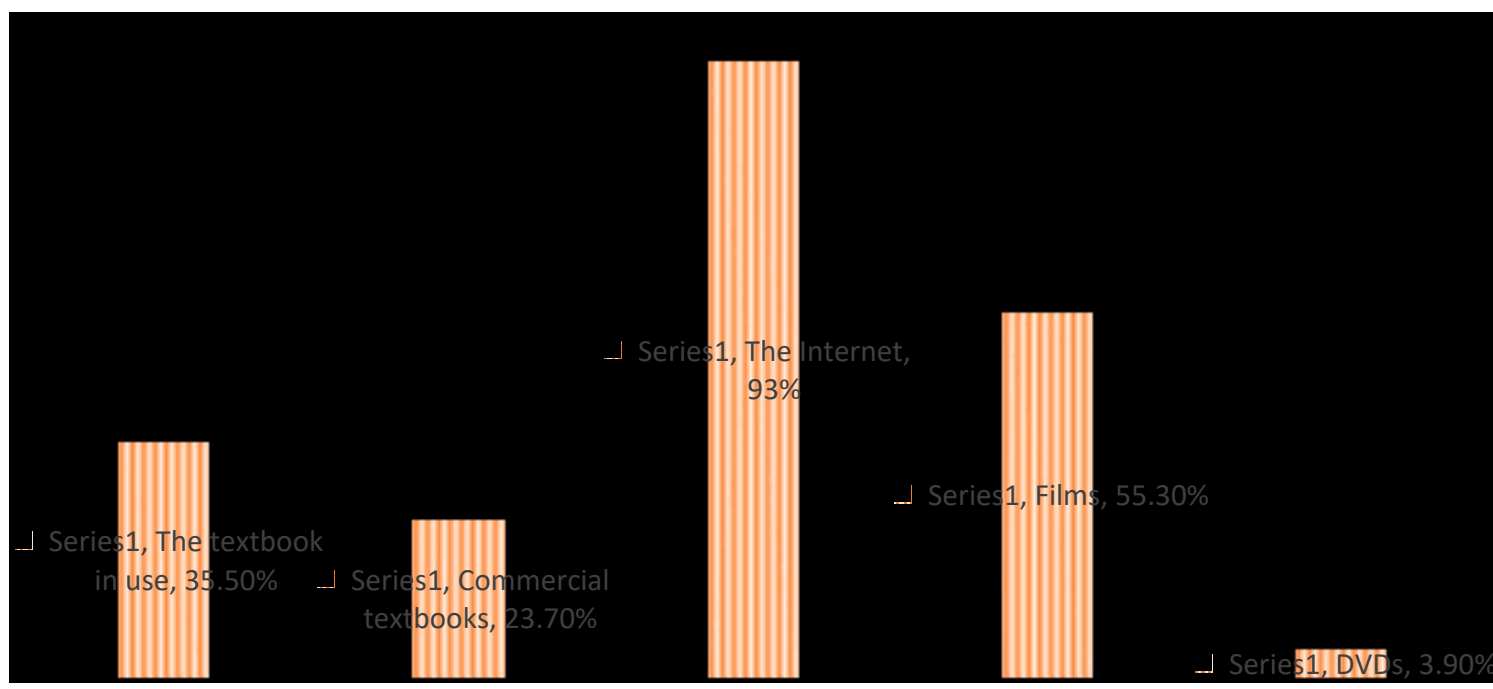

This item was meant to elicit data on the sources to which the participants resort to get information and guidance for their culture teaching. Figure 5 reveals that the Internet topped the list, followed by the textbooks in use. The choice of the Internet was hugely echoed in the interviews. Because it is an inexhaustible source of information about different cultures, the Internet was favored by all the respondents. It enables both teachers and students to access authentic teaching/learning materials, including videos and texts on cultures. It has been reported that the Internet, compared to other culture sources, is an effortless gate to compensate for the limited culture content in the textbooks. This content was described as outdated.

\section{Cluster 5. Challenges and recommendations}

Figure 6. Significant Challenges while Teaching Cultures

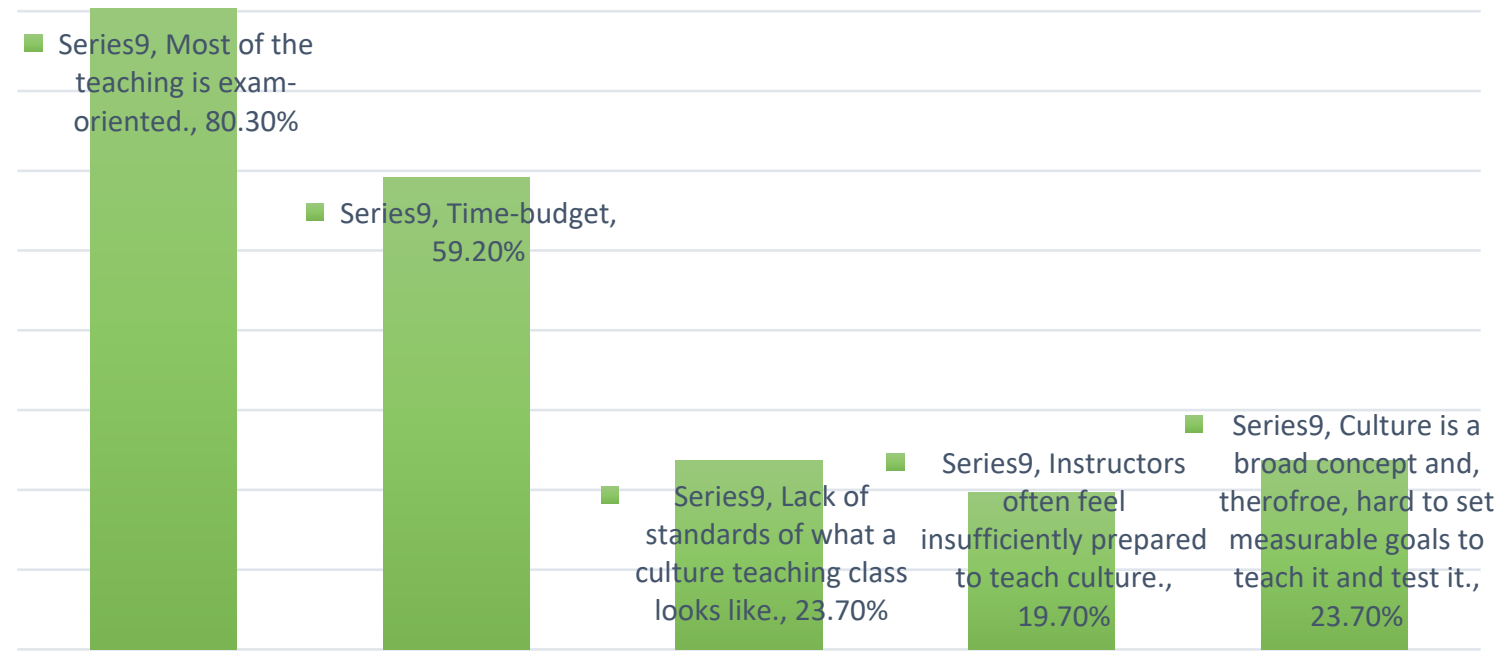

The reason for including this item was to elicit the significant challenges encountered by the EFL teachers in their incorporation of culture. Figure 6 displays that the culture of assessment, along with the limited time budget, tops the list of challenges. Also, the broadness of culture was reported to be another significant obstacle. Because it is too broad, it is hard to teach and assess. Based on the interview data, culture cannot be a priority in an 
educational setting where teachers are required to cover linguistically overloaded textbooks. The teachers' job is also reduced to helping students prepare for national exams in which culture is not tested.

\section{DISCUSSION}

As stated earlier, the purpose of this article was to explore the area of culture teaching in the Moroccan EFL context with special reference to the second-year Baccalaureate level. Data analysis has implied that the participants had a good understanding of theculture in the context of foreign language education. However, they admitted that classroom practices are far from being satisfactory.

First, almost all the participants considered culture as an inescapable component in EFL teaching/learning to the extent that most participants equated culture with communication. They thought that teaching the English language without addressing its culture cannot help learners communicate appropriately. This echoes Hall (1959) and Fantini (1997), who also equated culture with communication, assuming culture as fabrics of meanings we attributed to the world around us; a language is a tool that exteriorizes those perceptions of the world. In the same vein, Bennett (1993) pointed out that learning a second or foreign language is no more than a substitution process of words and rules to get the same intended meaning with different tools. Bennett continued that it is true that "language does serve as a tool for communication, but also, it is a system of representation for perception and thinking" (p. 16). By teaching a foreign language in isolation of its culture, teachers run the risk of producing what Bennett (1993) called "fluent fool". This refers to someone who speaks a foreign language fluently but does not understand the social or philosophical content of that language (p.16). This centrality of culture to language learning has been resonated by Kramsch (1998) in that language is a carrier of culture when used in communication.

Additionally, while the research participants argued that culture teaching should stress the culture whose language students are learning, they highly recommended that other world cultures should be referred to in EFL teaching.Their reasons are (1) the world has become globalized, and (2) the English language has become a lingua franca. That is, students should be prepared for unpredictable situations. This awareness was crosschecked via other questionnaire items; the teachers believe that the EFL teaching purpose should equip students with skills to interact appropriately with different people from different cultural backgrounds.

Second, data on the classroom practice imply that the respondents claimed to have integrating cultures in their EFL teaching. However, their inclusion of culture is oriented chiefly towards cultural products and cultural practices. The activities highlighting attitudes and values are seldom used. Qualitative data from the interviews further illuminated that perspectives-tied activities failed to receive attention, compared to both products and practices, for three significant reasons. First, exploring the underlying significance of products and practices requires a high level of language proficiency on the part of learners. Second, mandated textbooks seldom refer to the values, attitudes, beliefs, and perceptions governing both practices and products.Having analyzed the three textbooks used to teach English in Moroccan secondary schools, Bouzid (2017) concluded that the activities addressing cultural perspectives are underrepresented compared to those addressing products and practices. This under-representation of Brooks' (1968) deep culture, Fantini's (1997) mentifacts, and Hall's (1976) "submerged part" of the cultural iceberg can deprive EFL learners of the opportunities to understand the implicit meaning "that reflects members' perceptions of the world, the beliefs and values that they hold, and the norms, expectations, and attitudes that they bring to practices" (Moran, 2001, p. 74). Third, while identifying both cultural products and practices tends to be a little difficult for both students and teachers, the underlying cultural perspectives that sanction both products and practices remain challenging to identify as they are mostly intangible. 
Third, the data also revealed that the respondents were critical of the currently used textbooks with reference to the cultural content. They agreed that the course books do not treat language and culture equally. That is, attention has been given to grammar and other language skills. In contrast, culture has been relegated to the end of the thematic units and has implicitly made culture an "expendable fifth skill" (Kramsch, 1993, p.1). Compared to other language skills, this peripherality of culture has prompted the teachers to resort to other resources to get culture teaching materials. Among the primary sources highlighted were the Internet, films, and commercial textbooks.

Fourth, the findings additionally suggested that a wide array of hurdles still thwart the process of culture incorporation in the EFL classrooms at secondary schools. Among the widely reported challenges are the limited time budget, the culture of assessment, broad culture teaching goals, and insufficient training. These have altogether made linguistic features of the language pre-empt a significant amount of time in the classroom teaching. In congruence with these reported worries, Kramsch et al. (1996) argued that teachers are "illprepared to teach culture in the same principled way they teach grammar and vocabulary" ( $\mathrm{p}$. 99). Similarly, teachers argued that students tend to overlook those aspects of a course that are not assessed. Therefore, if culture is not a prerequisite aspect of the exam, learners will not consider it essential.

\section{RECOMMENDATIONS}

At the end of the questionnaire, the participants were asked to make recommendations for the development of culture teaching in the Moroccan EFL secondary classes. A content analysis of the suggested ideas has shown that:

1- More culture content should be injected into the textbooks;

2- Given the limited amount of time, cultural activities should stimulate learners to explore culture outside the classroom walls.

3-The number of English classes per week should be extended from 3hours a week to five or six hours so that teachers can have enough time to expose their learners to more cultures inside the language classrooms.

4- Because students tend to overlook those aspects of a course not assessed, it is highly recommended that culture be tested if teachers want students to consider it essential.

5- Since English is not spoken outside the classroom, ELT supervisors should encourage 'connecting classroom' in order to enable students/teachers to get in touch with native speakers online;

6-Teachers should be trained in how to integrate culture in conjunction with language;

7- Because "we cannot teach everything about culture" (Liddicoat, 2001, p. 54), teachers are required to foster more learner autonomy by adopting more student-centered teaching approaches.

8-Teaching practitioners should have access to data show, WIFI, and computers. These teaching materials can make the job of incorporating cultures easier.

\section{CONCLUSION}

The exploratory study has provided insights into the classroom practices of culture teaching at the second-year Baccalaureate level in the Moroccan EFL context. More specifically, the study addressed four major areas: (1) teachers' perceptions of incorporating cultures in EFL teaching, (2) the practices teachers use to facilitate the incorporation of culture in their classrooms, (3) teachers' perceptions of the textbook in use as a source of culture teaching, and (4) the challenges encountered while teaching cultures. The statistical and content analysis of the data gathered through questionnaires and interviews has revealed that the participants demonstrated a good understanding of culture teaching. However, while the participants claimed to diversify their cultural activities, the results have shown that the activities have failed to touch upon values, attitudes, perceptions, and beliefs that govern 
cultural products and practices. The participants also reported having encountered multiple challenges that frustrate the implementation of culture. Among the challenges highlighted are time-budget, the culture of assessment, and linguistically loaded textbooks.

While this study has some recommendations for EFL teachers, the findings should be cautiously considered in light of the following limitations. First, the study sample is small compared to the large number of EFL teachers working at Souss Massa Academy. Also, the data collection instruments were restricted to questionnaires and interviews. The results could differ if classroom observations had been included to cross-check the data elicited via questionnaires and interviews. Despite these limitations, the present study is significant for integrating cultures while teaching in an EFL classroom.

Researchers are recommended to replicate this in other research settings in Morocco since classroom practices and teaching practitioners' perceptions may differ from one area to another. Besides, future research should increase the number of participants to strengthen the validity and reliability of the results and generalize the results.

\section{REFERENCES}

Aleksandrowska, O. (2015). The educational potential of texts of culture in teaching English to senior secondary school students (Vol. 2). Peter Lang Edition.

Benattabou, D. (2020). Developing students' intercultural competence among Moroccan EFL students: Focus on raising their cross-cultural awareness. International Journal of Language and Literary Studies. (2), 3, pages 43-56.

Benattabou, D. (2020). On the teaching and learning of culture-loaded words: The case of Moroccan learners of EFL. International Journal of Linguistics and Translation Studies. Volume 1, Issue 3, October 2020, pages 1-19.

Benattabou, D. (2020). Helping EFL students avoid socio-pragmatic failure: Focus on nonverbal intercultural competence. TESOL and Technology Studies. 1, (1), pages 2341.

Bennett, M. J. (1993). How not to be a fluent fool: Understanding the cultural dimension of language. In A.E. Fantini (Ed.). New ways in teaching culture (pp. 16-21). Arlington, VA: TESOL

Bennett, M. J. (1998). Intercultural communication: A current perspective. In M. J. Bennett (Ed.), Basic concepts of intercultural communication: Selected readings (pp. 1-34). Intercultural Press. www.uiz.scholarvox.com

Bouzid, H. A. (2017). An evaluation of selected Moroccan ELT textbooks: A Standardsbased Approach perspective. Indonesian Journal of Applied Linguistics, 7(1), 229-238.

Brooks, N. (1968). Teaching culture in the foreign language classroom. Foreign language annals, 1(3), 204-217. https://doi.org/10.1111/j.1944-9720.1968.tb00135.x

Brown, H. D. (2000). Principles of language teaching and learning. New York: Longman

Byram, M. (1989). Cultural studies in foreign language education (Vol. 46). Multilingual Matters. 
Byram, M. (2008). From foreign language education to education for intercultural citizenship: Essays and reflections (Vol. 17). Multilingual Matters.

Cook, M. A. (1972) Suggestions for developing more positive attitudes toward native speakers of Spanish. In H. N. Seelye (Ed.), Teaching cultural concepts in Spanish classes (pp. 97-107). Springfield, Office of the Superintendent of Public Instruction.

Dahl, Ø. (2016). Human encounters: Introduction to intercultural communication. Peter Lang Limited, International Academic Publishers. https://uiz.scholarvox.com

Damen, L. (1987). Culture learning: The fifth dimension in the language classroom (Vol. 11478). Addison Wesley Publishing Company.

Dema, O., \& Moeller, A. K. (2012). Teaching culture in the 21 st century language classroom.

Fantini, A. E. (1997). Language: Its cultural and intercultural dimensions. In A.E. Fantini (Ed.), New ways in teaching culture (pp. 3-15). Arlington, VA: TESOL

Fantini, B, C., \& Fantini, A. E. (1997). Artifacts, sociofacts and mentifacts: A sociocultural framework. In A.E. Fantini (Ed.). In A.E. Fantini (Ed.). New ways in teaching culture (pp. 57-61). Arlington, VA: TESOL.

Grittner, F. (1990). Bandwagons revisited: A perspective on movements in foreign language education. In W. D. Birckbichler (Ed.), New perspectives and new directions in foreign language education, (pp. 9-43). National Textbook Company.

Hall, E. T. (1959). The silent language (Vol. 948). Anchor books.

Jiang, W. (2000). The relationship between culture and language. ELT journal, 54(4), 328334.

Kramsch, C. (1998). Language and culture. Oxford University Press.

Kramsch, C. (1993). Context and culture in language teaching. Oxford University Press.

Kramsch, C., Cain, A., \& Murphy, L. E. (1996). Why should language teachers teach culture? Language, Culture and Curriculum, 9(1), 99-107.

Lado, R. (1986). How to compare two cultures. In J. M. Valdes (Ed.), Culture bound: Bridging the cultural gap in language teaching (pp. 52-63). Cambridge University Press.

Lafayette, R. C. (1978). Teaching culture: Strategies and techniques. Language in Education: Theory and Practice, No. 11.

Lange, D. L. (2003). Future directions for culture teaching and learning: The implications of the new culture standards and theoretical frameworks for curriculum, assessment, instruction, and research. In D. L. Lange \& R.M. Paige (Eds.), Culture as the core: Perspectives on culture in second language learning (pp. 337-354). Information Age Publishing Inc. 
Larsen-Freeman, D. (2000). Techniques and principles in language teaching. Oxford University.

Liddicoat, A. (2001). Static and dynamic views of culture and intercultural language acquisition. New Zealand Language Teachers, 27, 47-58.

Mahmoud, M. M. A. (2015). Culture and English language teaching in the Arab world. Adult Learning, 26(2), 66-72.

Mimouni, A., \& Tamer, Y. (2020). The Effect of Music on Moroccan Students' Acceptance of Kahoot Gamified Quizzing in the EFL Classroom. International Journal of Language and Literary Studies, 2(2), 210-220. https://doi.org/10.36892/ijlls.v2i2.303

Moran, P. R. (2001). Teaching culture: Perspectives in practice. Boston, MA: Heinle \& Heinle.

Pesola, C. A. (1997). Culture and the curriculum in the elementary school foreign language classroom. In P.R. Heusinkveld (Ed.), Pathways to culture, (pp. 173-190). Intercultural press.

Peterson, B. (2004). Cultural intelligence: A guide to working with people from other cultures. Nicholas Brealey Publishing.

Phillips, J. K. (2003). National standards for foreign language learning: Culture the driving force. In D. L. Lange \& R.M. Paige (Eds.), Culture as the core: Perspectives on culture in second language learning (pp. 161-171). Information Age Publishing Inc.

Quist, G. (2000). Culture in the university foreign language curriculum: Some theoretical considerations. Dutch Crossing, 24(1), 3-28.

Reid, E. (2014). Intercultural aspects in teaching English at primary schools. Peter Lang Edition. https://uiz.scholarvox.com

Risager, K. (2007). Language and culture pedagogy: From a national to a transnational paradigm. Multilingual Matters.

Robinson, S. G., \& Nocon, H. (1996). Second culture acquisition: Ethnography in the foreign language classroom. The Modern Language Journal, 80(4), 431- 449.

Schulz, R. A. (2007). The challenge of assessing cultural understanding in the context of foreign language instruction. Foreign Language Annals, 40 (1), 9-26.

Seelye, H. N. (1984). Teaching culture: Strategies for intercultural communication ( $3^{\text {rd }}$, ed.). National Textbook Company.

Spinelli, E., \& Siskin, H. J. (1992). Selecting, presenting, and practicing vocabulary in a culturally-authentic context. In P.R. Heusinkveld (Ed.), Pathways to culture, (pp. 225245). Intercultural press.

Steele, R. (1989). Teaching language and culture: Old problems and new approaches. In J. E. Alatis (Ed.), Georgetown university roundtable on languages and linguistics, (153162). Georgetown University Press. 
Strasheim, L. A. (1981). Language is the medium, culture is the message: Globalizing foreign languages. https://archive.org

Ting-Toomey, S. (1999). Communicating across cultures. Guilford Press.

Valdes, J. (1990). The inevitability of teaching and learning culture in a foreign language course. In H. Brian (Ed.), Culture and the language classroom (pp. 20-30). Hong Kong: Modern English Publications.

Wintergerst, A. C., \& McVeigh, J. (2011). Tips for teaching culture: Practical approaches to intercultural communication. Harlow, England: Pearson Education.

Yang, X., \& Chen, D. (2016). Two barriers to teaching culture in foreign language classroom. Theory and Practice in Language Studies, 6(5), 1128.

\section{$\underline{\text { AUTHORS' BIO }}$}

Mohamad Akharraz is an EFL instructor. He is a PhD student at Ibn Zohr University, Morocco. His areas of interest are cultural studies and applied linguistics.

Email address: moahamad.akharraz@edu.uiz.ac.ma

Dr. Youssef Tamer is a Professor of Applied Linguistics at Ibn Zohr University, Morocco. His research is focused on Teaching and Learning of Languages, Sociolinguistics, Language Planning and Policy, and Educational Technology.

Email address:y.tamer@uiz.ac.ma 